Volume 13 Nomor 1, November 2021, p. 016-032.

Faculty of Law, Universitas Kristen Maranatha

ISSN: 2085-9945 I e-ISSN: 2579-3520

Nationally Accredited Journal by SINTA

\title{
URGENSI PEMIDANAAN BAGI PELAKU PERDAGANGAN PENGARUH (TRADING IN INFLUENCE) DARI KALANGAN NON PEJABAT PUBLIK DALAM RANGKA PEMBERANTASAN TINDAK PIDANA KORUPSI
}

\author{
Joice Viladelfia, Rahel Octora \\ Fakultas Hukum Universitas Kristen Maranatha \\ octorael@gmail.com
}

Submitted: 2021-06-07 | Reviewed: 2021-09-13 | Accepted: 2021-11-08

How to cite: Joice Viladelfia dan Rahel Octora. "Urgensi Pemidanaan Bagi Pelaku Perdagangan Pengaruh (Trading in Influence) dari Kalangan Non Pejabat Publik Dalam Rangka Pemberantasan Tindak Pidana Korupsi”. Dialogia Iuridica: Jurnal Hukum Bisnis dan Investasi, Vol. 13, No. 1, (2021), 016032.

DOI:

https://doi.org/10.28932/di.v13i1.3660

\begin{abstract}
Trading in influence happens in Indonesia, in many kinds of ways. In Indonesia, there is no specific regulations concerning trading in influence. Trading in influence is mostly carried out by both public officials and non-public officials, who have access to public authorities. Until now, the settlement of trading in influence cases has been completed by applying the rules on bribery.
\end{abstract}

This paper discusses how the regulation of trading in influence by non-public officials is related to the enactment of the Corruption Crime Act, as well as how the urgency of criminalizing the act of trading in influence in order to optimize the eradication of Corruption. This study aims to examine how the Indonesian criminal law system regulates the act of trafficking in influence and examines the urgency of criminalizing this act. This research uses a juridical-normative method, with a statutory approach and a conceptual approach. Data collection is carried out by means of a literature study. This data processing is processed and analyzed qualitatively. 
The result of this research is that the legal system in Indonesia (the Anti-Corruption Law) has not strictly regulated the actions of Trading Influence, so it is necessary to revise the AntiCorruption Law, to include the rules of Trading Influence. The formulation of the offense of trading in influence in Indonesia as part of a criminal act of corruption is considered very urgent in order to optimize the eradication of corruption.

Keywords: Corruption, Non-Public Official, Trading in Influence

\section{PENDAHULUAN}

Korupsi menjadi sebuah permasalahan kompleks yang terjadi di berbagai negara. Pengaruh negatif korupsi di suatu negara biasanya bersifat sistemik dan masif. Terhambatnya pembangunan infrastruktur, meningkatnya kemiskinan, dan terganggunya pertumbuhan ekonomi suatu negara akibat menurunnya investasi, menjadi beberapa hal serius yang perlu mendapatkan perhatian. Masalah korupsi bukanlah suatu masalah baru dalam persoalan hukum dan ekonomi suatu negara, karena pada dasarnya masalah korupsi telah ada sejak ribuan tahun lalu. ${ }^{1}$ Setiap negara tentunya berupaya membangun sistem regulasi yang baik dalam rangka pencegahan dan pemberantasan tindak pidana korupsi. Tindak pidana korupsi diatur di dalam Undang-undang Nomor 20 Tahun 2001 Tentang Perubahan Atas Undang-undang Nomor 31 Tahun 1999 Tentang Pemberantasan Tindak Pidana Korupsi (PTPK).

Perkembangan modus tindak pidana korupsi juga menjadikan pemerintah harus senantiasa memperhatikan keberlakuan aturan. Perlu ditinjau apakah peraturan yang berlaku saat ini telah mampu menjangkau berbagai modus baru yang berkembang. Fenomena korupsi yang terjadi akhir-akhir ini mengalami perkembangan yang begitu kompleks baik dari segi modus dan aktor, tindak pidana korupisi yang semakin canggih dan variatif artinya korupsi perbuatan yang berkembang secara dinamis, ${ }^{2}$ hal ini mengakibatkan penegak hukum mengalami kesulitan utuk memproses kasus-kasus yang mengandung modus-modus baru.

Kasus korupsi yang terjadi saat ini, tidak hanya berkenaan dengan aktivitas melawan hukum yang dilakukan oleh pejabat negara yang menimbulkan kerugian keuangan negara, namun mungkin pula terjadi di luar ruang lingkup tersebut. Pelaku tidak dapat digolongkan sebagai pejabat publik. Tindakan yang berkaitan dengan korupsi, yang berpotensi dilakukan oleh golongan non pejabat publik adalah tindakan perdagangan

Edi Yunara, Korupsi dan Pertanggungjawaban Pidana Korporasi, Bandung: PT Citra Aditya Bakti, 2005, hlm.1

2 Sari Mandina, Hukum Pidana Masa Kini: Perspektif Jurimetrie Pada Kebijakan Legislasi Pemberantasan Tindak Pidana Koruspsi, Yogyakarta: Total Media, 2014, hlm. 84 
pengaruh atau diistilahkan dengan trading in influence. Tindakan ini belum mendapatkan pengaturan yang komprehensif dalam sistem hukum pidana Indonesia, meskipun secara internasional sudah disepakati dalam United Nation Convention Against Corruption (UNCAC) yang kemudian diratifikasi melalui Undang-Undang No. 7 Tahun 2006.

Artidjo Alkostar mendefinisikan trading in influence atau dapat disebut perdagangan pengaruh adalah suatu tekanan yang mempengaruhi sikap orang untuk menentukan pendapatnya sehingga dengan demikian lebih bersifat tekanan, di mana tekanan dapat berupa: (1) tekanan kekuasaan politik, dan (2) tekanan ekonomi. Dalam arti kata memberi janji, apa pun bentuknya yang berupa yang menguntungkan bagi orang yang mau dan dapat dipengaruhi. ${ }^{3}$ Oleh karena itu, pelaku trading in influence memiliki konsep hanya dapat dilakukan oleh orang-orang yang memiliki kekuasaan. Harold D.Laswel mendefinisikan kekuasaan sebagai suatu hubungan di mana sesorang atau sekelompok orang dapat menentukan tindakan seseorang atau kelompok lain ke arah pihak pertama, kekuasaan merupakan kemampuan seseorang pelaku untuk mempengaruhi pelaku seorang pelaku lain dalam hal ini kekuasaan selalu berlangsung minimal antara dua pihak jadi di antara pihak itu terkait atau saling berhubungan. ${ }^{4}$

Demikian pula konsep tindakan "trading in influence" sangat berkaitan dengan konsep kekuasaan. Trading in influence berkaitan dengan dimilikinya kekuasaan oleh seseorang, dan adanya akses terhadap kekuasaan tersebut pada seorang lainnya. Akses yang dimaksud dapat berupa kedekatan personal. Dengan demikian, pihak yang memiliki akses tersebut dapat memanfaatkan situasinya untuk memperdagangkan pengaruh.

Trading in Influence merupakan hal yang baru bagi pemberantasan korupsi di Indonesia, mengingat belum ada aturan yang secara eksplisit mengatur tindakan ini sebagai tindak pidana tersendiri. Di Indonesia, pengenaan sanksi bagi pelaku seringkali dikaitkan dengan tindakan suap dan / atau gratifikasi. Hal ini berbeda dengan yang terjadi di negara-negara Eropa, yang telah mengenal delik trading in influence ini. Dasar dari penegakan hukum negara dan masyarakat dunia untuk menentang tindak pidana korupsi adalah dengan ditandatanganinya The United Nations Convention Against Corruption (UNCAC) yang merupakan wujud perhatian dari negara-negara di dunia atas keseriusan masalah dan ancaman yang ditimbulkan oleh tindak pidana korupsi. Trading in Influence diatur dalam Pasal 18 huruf (a) dan (b) tentang trading in influence (perdagangan pengaruh). ${ }^{5}$

Kasus perdagangan pengaruh di Indonesia pernah terjadi dengan berbagai modus. Salah satu kasus yang mengandung unsur memperdagangkan pengaruh (Trading in Influence) adalah kasus impor daging sapi dengan terdakwa Luthfi Hasan Ishaaq (LHI) Cs, dan anggota DPR RI, yang diduga memperdagangkan pengaruhnya. Di dalam surat

Tim Peneliti Indonesia Corruption Watch, Kajian Implementasi Aturan Trading in Influence Dalam Hukum Nasional, Jakarta, ICW.2014. hlm. 45.

Miriam Budiarjo, Dasar-Dasar Ilmu Poltik, Jakarta: Gramedia Pustaka Utama,2007 hlm. 59-70.

Andi Hamzah, Pemberantasan Korupsi melalui Hukum Pidana Nasional dan Internasional Jakarta:Raja Grafindo Persada, 2007, hlm. 251. 
dakwaan disebutkan bahwa bahwa LHI "memperdagangkan pengaruhnya". Unsur "memperdagangkan pengaruh" belum dapat dianggap sebuah unsur delik yang dikaitkan dengan berlakunya pasal tertentu, karena tidak ada di dalam UU PTPK, pasal yang mengatur unsur "memperdagangkan pengaruh".

Pada kasus ini pihak yang dianggap memperdagangkan pengaruh, menerima sejumlah uang sehingga dalam hal ini Jaksa Penuntut Umum mendakwa dengan menggunakan pasal suap. Apabila ditinjau lebih lanjut, sebenarnya terdapat perbedaan mendasar antara unsur Trading in Influence dengan unsur suap. Unsur suap mengindikasikan adanya pemberian dana oleh pelaku suap dan penerimaan dana oleh pihak yang diminta untuk melakukan sesuatu yang bertentangan dengan tugas dan tanggungjawab jabatannya. Apabila dalam kasus di atas tidak terjadi penerimaan sejumlah uang oleh yang memperdagangkan pengaruhnya, akan berakibat pihak yang memperdagangkan pengaruh tersebut tidak dapat dikenai sanksi.

Penelitian ini menggunakan metode penelitian hukum, yang menggunakan jenis penelitian yuridis-normatif, yakni dilakukan dengan cara menelaah dan menginterpretasikan hal-hal yang bersifat teoritis yang menyangkut asas, doktrin-doktrin dan norma hukum yang berkenaan isu hukum yang ada. Sifat penelitian yang digunakan adalah deskriptif-analisis. Metode pendekatan yang digunakan adalah statute approach (pendekatan perundang-undangan), dan conceptual approach (pendekatan konseptual). Teknik pengumpulan data yang digunakan melalui metode library research (metode kepustakaan) dengan munguji bahan dokumen dan bahan pustaka yang digunakan dalam penelitian ini.

Berdasarkan penelusuran yang dilakukan, terdapat jurnal serupa yang membahas topik Trading In Influence dari sudut pandang hukum Indonesia, di antaranya karya Rikky Adhi Susilo, Dr. Bambang Sugiri, SH., MS., dan Dr. Ismail Novianto, SH., MH. dengan judul 'Kriminalisasi Perdagangan Pengaruh (Trading In Influence) Sebagai Tindak Pidana Korupsi', yang dimuat dalam Kumpulan Jurnal Mahasiswa Fakultas Hukum Universitas Brawijaya, tahun 2016. Pada jurnal tersebut penelitian terfokus pada bentuk formulasi aturan dalam rangka mengkriminalisasi tindakan trading in influence. Selain itu terdapat jurnal yang berjudul 'Kriminalisasi Trading In Influence Dalam Pemberantasan Tindak Pidana Korupsi', karya I Gusti Ayu Werdhiyani, I Wayan Parsa dari Fakultas Hukum Universitas Udayana, yang dimuat dalam Jurnal Kertha Wicara tahun 2020. Penelitian tersebut membahas bagaimana Indonesia harus merumuskan pengaturan Trading in Influence sebagai konsekuensi dari ratifikasi UNCAC.

Sedangkan penelitian ini terfokus pada kajian tentang hukum positif yang saat ini berlaku dan kriminalisasi bagi subjek yang bersifat khusus yaitu pihak non pejabat publik. Dengan demikian, penelitian ini berbeda dengan penelitian yang telah ada sebelumnya. Penelitian ini bertujuan untuk mengkaji dan memahami:

1. Bagaimana pengaturan tindakan perdagangan pengaruh (Trading in Influence) oleh subjek hukum yang tidak tergolong sebagai Pejabat Publik dihubungkan dengan berlakunya Undang-Undang Tindak Pidana Korupsi? 
2. Bagaimana urgensi kriminalisasi tindakan perdagangan pengaruh (trading in influence) dalam rangka optimalisasi pemberantasan Tindak Pidana Korupsi?

\section{PEMBAHASAN}

\section{Pengaturan Tindakan Perdagangan Pengaruh (Trading In Influence) Oleh Non Pejabat Publik Dihubungkan Dengan Berlakunya Undang-Undang Tindak Pidana Korupsi (TIPIKOR).}

Korupsi secara harfiah merupakan suatu tindakan peyelewengan atau penggelapan untuk kepentingan orang lain atau diri pribadi berupa hal yang jahat dan merusak. ${ }^{6}$ Saat ini, korupsi tidak dapat diidentikan dengan kejahatan yang terjadi di kalangan pejabat publik saja. Kasus korupsi saat ini dapat melibatkan pelaku dari sektor swasta atau di luar kalangan pejabat publik. Hal yang dapat dianggap sebagai kelemahan dalam penegakan hukum di Indonesia, adalah bahwa di Indonesia upaya pencegahan dan penindakan masih terkonsentrasi pada sektor publik saja. Studi yang dilakukan oleh peneliti dari Univesitas Gajah Mada menunjukan hasil bahwa terdapat 670 pelaku korupsi dari sektor swasta atau non pejabat publik menjadi terdakwa dalam kasus korupsi antara tahun 2001 dan $2015 .^{7}$ Modus yang dilakukan di antaranya dengan memperdagangkan pengaruh.

Trading in Influence pertama kali diatur dalam United Nations Convention Against Corruption (UNCAC) pada konvensi Perserikatan Bangsa-Bangsa (PBB). Hal ini guna memerangi korupsi dan menentang adanya korupsi, UNCAC telah disahkan dalam Konferensi Diplomatik di Merida, Mexico pada bulan Desember tahun 2003 dan terbuka untuk ditandatangani oleh Negara Peserta Konvensi. Sidang Majelis Umum PBB dengan Resolusi Nomor 57/169 telah mengadopsi draft Konvensi PBB sebagai dokumen yang sah dan siap untuk ditandatangani oleh Negara Peserta Konvensi tanggal 9 sampai dengan tanggal 11 Desember 2003. ${ }^{8}$ Salah satu negara yang sudah menandatangani Konvensi tersebut adalah Indonesia, Indonesia sudah meratifikasi Konvensi tersebut kedalam Undang-Undang Nomor 7 Tahun 2006 pada 19 September 2006. Dengan diratifikasinya konvensi tersebut, Indonesia sudah berkomitmen untuk memberantas atau mencegah adanya tindakan Trading in Influence. Melalui ratifikasi tersebut, Indonesia diwajibkan memiliki empat Undang-undang, salah satunya penanganan korupsi antar sektor swasta. ${ }^{9}$ Beberapa negara sudah menerapkan ketentuan yang terkait trading in influence, di antaranya negara Spanyol, Belgia dan Perancis.

Regulasi ini menjadi penting untuk mengantisipasi terjadinya korupsi di sektor non pejabat publik atau swasta dengan berbagai modus yang terus berkembang.

Evi Hartanti, Tindak Pidana Korupsi, Jakarta: Sinar Grafika, 2014, hlm. 9.

Anti Corruption Clearing House, "Upaya KPK Menangani Korupsi di Sektor Swasta", https://acch.kpk.go.id/id/component/content/article?id=166:upaya-kpk-menangani-korupsi-di-sektorswasta, diakses pada tanggal 15 Januari 2021, Pukul 11.00.

8 Forum Pemantau Pemberantasan Korupsi, United Nations Convention Against Corruption (UNCAC) 2003 terjemahan, Jakarta: Perum Percetakan Negara RI, 2004, hlm. 5.

9 Kabar 24, "UU Korupsi Sektor Swasta Harus Segera Hadir, Kenyamanan Investasi Lebih Terjamin”, Https://Kabar24.Bisnis.Com/Read/20180221/16/741434/Uu-Korupsi-Sektor-SwastaHarus-Segera-Hadir-Kenyamanan-Investasi-Lebih-Terjamin, diakses Pada Tanggal 15 Januari 2021, Pukul 11.00. 
Perkembangan modus dan aktor korupsi yang terjadi belakangan ini menunjukkan bahwa aktor intelektual dari kejahatan korupsi seringkali muncul dari kekuatan politik yang bukan dari seorang penyelenggara negara atau non pejabat publik dengan cara memperdagangkan pengaruh yang dimilikinya (trading in influence). Non pejabat publik tersebut memiliki akses atau kekuasaan kepada otoritas publik. Hal ini dapat ditemukan pada frasa "public official or any other person" (Pasal 18 Huruf (a) UNCAC). Bentuk perbuatan pihak yang telibat ada dalam trading in influence tersebut tidak memiliki pertentangan secara langsung dengan kewajiban atau kewenanganya. Dalam ketentuan tersebut sangat jelas dikatakan bahwa mengenai siapapun pelaku trading in influence baik dari pejabat publik maupun non pejabat publik, yang dalam hal ini memiliki akses birokrasi kepada otoritas publik yang mempunyai kebijakan. ${ }^{10}$

Secara umum, terminologi Trading in Influence menunjuk pada suatu perbuatan dengan maksud menjanjikan penawaran atau pemberian sesuatu baik secara langsung maupun tidak langsung kepada pejabat publik atau seseorang hal ini untuk memperoleh suatu keuntungan. ${ }^{11}$ Artinya dalam hal ini adanya istilah "keuntungan yang tidak semestinya" termasuk lingkup yang luas karena adanya sesuatu yang ditawarkan atau dijanjikan pada pejabat publik atau orang lain. ${ }^{12}$ Oleh karena itu, trading in influence memiliki konsep hanya dapat dilakukan oleh orang-orang yang memiliki kekuasaan.

Memperdagangkan pengaruh atau trading in influence merupakan janji atau hadiah atau penerimaan kepada siapa pun baik secara langsung maupun tidak langsung dengan maksud agar orang tersebut menyalahgunakan pengaruhnya kepada pejabat publik agar memperoleh keuntungan yang tidak semestinya dari tindakan pejabat publik untuk kepentingan pihak ketiga. ${ }^{13}$

Trading in Influence dalam hal ini merupakan bentuk trilateral relationship dalam korupsi. Terdapat tiga pihak yang terlibat dalam modus tersebut yaitu:

1. 2 (dua) pelaku dari sisi pengambil kebijakan termasuk orang-orang yang telah menjual pengaruhnya (di mana pihak yang menjual pengaruh, tidak harus pejabat atau penyelenggara negara),

2. 1 (satu) pelaku yang memberi sesuatu untuk mendapatkan keuntungan dari pejabat publik penyelenggara negara.

Di dalam Trading in Influence terdapat 2 (dua) pola yaitu:

a. Pola Vertikal

Model trading in influence dengan pola vertikal biasanya terjadi karena adanya transaksi politik atau Lembaga tertentu dengan orang yang memliki

10 Alvin Saputra Dan Ahmad Mahyani, Tinjauan Yuridis Trading in Influence Dalam Tindak Pidana Korupsi, Mimbar Keadilan Jurnal Ilmu Hukum, 2017, hlm.85.

11 J Kristiadi, Bersatu Melawan Perdagangan Pengaruh, Harian Kompas Edisi 24 November 2015, hlm. 15 .

12 Julia Philipp, The Criminalisation of Trading in Influence in International AntiCorruption Laws, Faculty of Law, University of the Western Cape, South Africa, 2009, hlm. 35.

13 Anis Lailatul Fajriah, et.al., Perdagangan Pengaruh (Trading In Influence) Ditinjau Dari Perspektif United Nations Convention Against Corruption (UNCAC), e-Journal Komunitas Yustisia, Universitas Pendidikan Ganesha Program Studi Ilmu Hukum (Volume 4 Nomor 2 Agustus 2021), hlm. 557-558. 
pengaruh. Dalam model trading in influence pola ini, pihak yang memilki pengaruh merupakan seseorang yang memilki kekuasaan atau kewenangannya dan pengaruh yang dimilikinya digunakan untuk memberikan insentif kepada perorangan atau suatu kelompok tertentu. ${ }^{14}$ Pola Vertikal dapat diilustrasikan sebagai berikut:

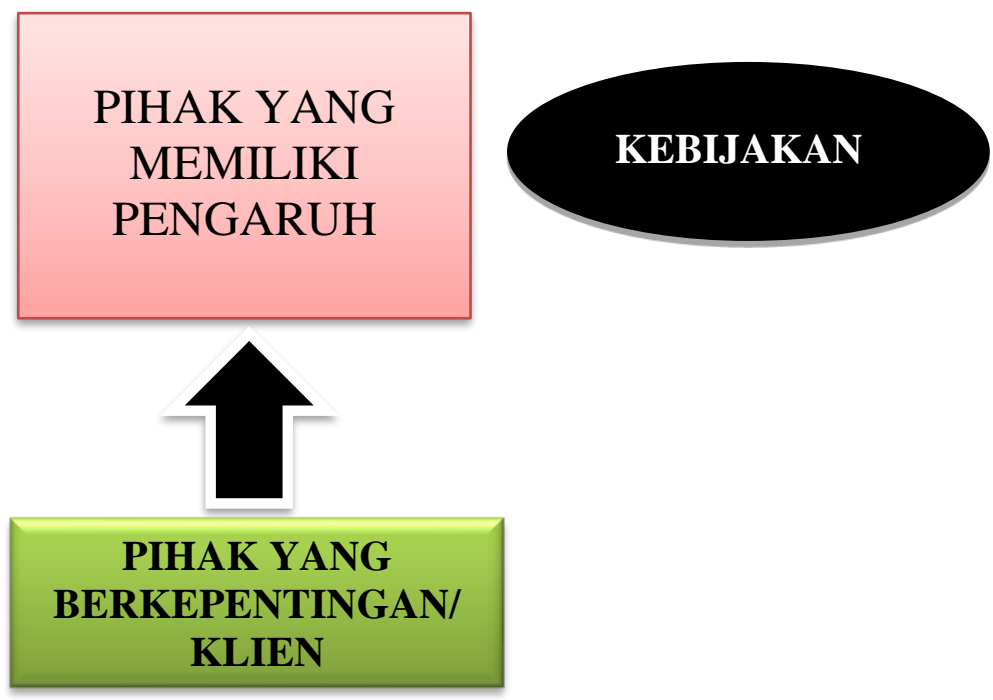

Gambar 1. Pola Vertikal

b. Pola Horizontal

Pihak yang berkepentingan atau klien bersama penjual pengaruh merupakan dua pihak yang aktif, sementara otoritas pejabat publik merupakan pihak yang dipengaruhi. Klien menyerahkan uang kepada pihak yang berpengaruh yang bukan penyelenggara negara. Pola horizontal banyak terjadi di lingkup partai politik yang memiliki jaringan kepada kekuasaan eksekutif. Orangorang yang berada di struktur pemerintah dalam mengambil kebijakan sering dipengaruhi oleh faktor eksternal, terutama yang berasal dari partai politiknya sendiri. ${ }^{15}$ Pola Horizontal dapat diilustrasikan sebagai berikut:

14 Policy Paper, Kajian Implementasi Aturan Trading in Influence, Jakarta: Indonesia Corruption Watch, 2014, hlm. 29.

15 Ibid., hlm. 33-34 


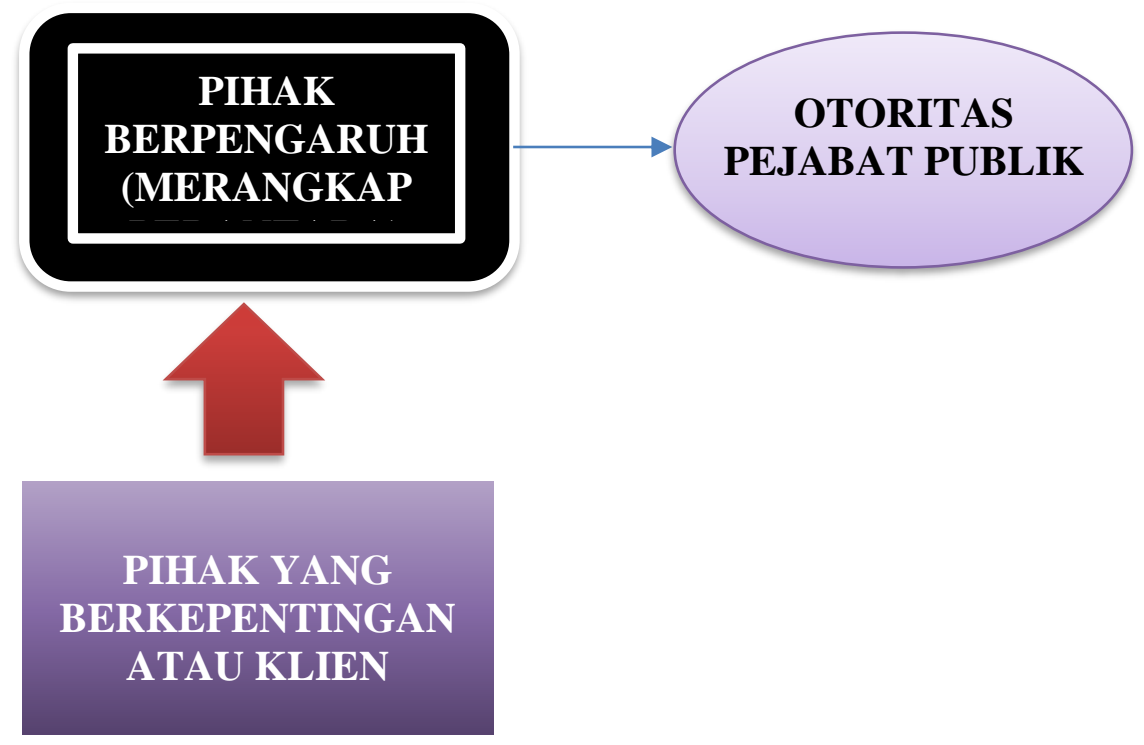

Gambar 2. Pola Horizontal

Beberapa contoh kasus yang pernah terjadi di Indonesia di antaranya kasus perdagangan pengaruh dalam kasus penetapan kuota impor daging sapi yang melibatkan Ahmad Fathanah dan Lutfi Hasan Ishaq. Lutfi Hasan Ishaq memperdagangkan pengaruhnya dalam kedudukannya sebagai presiden partai untuk mempengaruhi Menteri Pertanian yang merupakan bawahannya dalam partai tersebut untuk menambah kuota impor daging sapi bagi PT. Indoguna Utama. Dalam hal ini telah terjadi tindakan memperdagangkan pengaruh di mana pihak yang melakukannya bertindak secara aktif untuk mempengaruhi Menteri Pertanian. Hal ini merupakan trading in influence dalam pola horizontal di mana pihak yang berkepentingan yaitu Ahmad Fathanah bekerjasama dengan Lutfi Hasan Ishaq.

Kasus lain yang pernah terjadi adalah kasus kasus perdagangan pengaruh yang dilakukan oleh Choel Malarangeng terhadap PT Adhi Karya, dalam proyek pembangunan sport center Hambalang. Saat itu Choel Malarangeng memperdagangkan pengaruhnya mengingat hubungannya sebagai adik dari Menpora Andi Malarangeng.

Dengan demikian, trading in influence baik dalam pola vertikal maupun horizontal, dapat melibatkan pihak baik pejabat publik maupun non pejabat publik yang memiliki akses terhadap kekuasaan. Trading in Influence merupakan sebuah bentuk yang relatif sulit dipahami. Hal ini dikarenakan Trading in Influence memiliki tingkat kerumitan tersendiri.

UU Tipikor mengenal delik suap. Pada prinsipnya delik suap mensyaratkan adanya unsur:

1. pemberian barang sesuatu atau janji

2. kepada penyelenggara negara

3. dengan tujuan penyelenggara negara melakukan sesuatu dalam jabatannya

4. perbuatan tersebut menyimpang dari kewajibannya menurut jabatannya. 
Selain suap, UU Tipikor juga mengatur gratifikasi di dalam Pasal 12 B dan 12 C, yang pada dasarnya memilik unsur:

1. pemberian dalam arti seluas-luasnya

2. kepada penyelenggara negara

3. berhubungan dengan jabatannya

4. berlawanan dengan kewajiban / tugas jabatannya.

Bentuk perbuatan pada trading in influence dimana tindakan pelaku tidak memiliki pertentangan secara langsung dengan kewajiban atau kewenangannya. Sedangkan pada suap, salah satu unsur utama dalam suap adalah perbuatan pelaku yang bertentangan dengan kewajiban atau kewenangannya atau menurut pikiran pemberi tindakannya ada hubungannya dengan jabatan si penerima. ${ }^{16}$

Terhadap kasus-kasus di atas, para terdakwa dikenai sanksi hukum berdasarkan berlakunya delik suap sebagaimana pasal yang didakwakan terhadapnya, Pasal 5, Pasal 11, dan Pasal 12 huruf a dan b UU No 31 Tahun 1999 tentang Pemberantasan Tindak Pidana Korupsi (UU PTPK) sebagaimana diubah dengan UU No 20 Tahun 2001. ${ }^{17}$ Perbuatan suap dalam UU PTPK dan perubahannya di antaranya diatur dalam Pasal 5 UU 20 tahun 2001, berbunyi:

1) Dipidana dengan pidana penjara paling singkat 1 (satu) tahun dan paling lama 5 (lima) tahun dan atau pidana denda paling sedikit Rp 50.000.000,00 (lima puluh juta rupiah) dan paling banyak Rp 250.000.000,00 (dua ratus lima puluh juta rupiah) setiap orang yang:

a. memberi atau menjanjikan sesuatu kepada pegawai negeri atau penyelenggara negara dengan maksud supaya pegawai negeri atau penyelenggara negara tersebut berbuat atau tidak berbuat sesuatu dalam jabatannya, yang bertentangan dengan kewajibannya; atau

b. memberi sesuatu kepada pegawai negeri atau penyelenggara negara karena atau berhubungan dengan sesuatu yang bertentangan dengan kewajiban, dilakukan atau tidak dilakukan dalam jabatannya.

2) Bagi pegawai negeri atau penyelenggara negara yang menerima pemberian atau janji sebagaimana dimaksud dalam ayat (1) huruf a atau huruf $b$, dipidana dengan pidana yang sama sebagaimana dimaksud dalam ayat (1).

Pasal 11: Dipidana dengan pidana penjara paling singkat 1 (satu) tahun dan paling lama 5 (lima) tahun dan atau pidana denda paling sedikit Rp 50.000.000,00 (lima puluh juta rupiah) dan paling banyak Rp 250.000.000,00 (dua ratus lima puluh juta rupiah) pegawai negeri atau penyelenggara negara yang menerima hadiah atau janji padahal diketahui atau patut diduga, bahwa hadiah atau janji tersebut diberikan karena kekuasaan atau

16 Donal Fariz, dkk, Kajian Implementasi Aturan Trading In Influence Dalam Hukum Nasional, Jakarta: Indonesia Corruption Watch, 2014, hlm. 36.

17 Hukum online, "Pasal untuk Menjerat Pelaku Suap di Sektor Swasta", https://www.hukumonline.com/klinik/detail/ulasan/lt5f086878a3f65/pasal-untuk-menjerat-pelakusuap-di-sektor-swasta/, diakses Pada Tanggal 20 Mei 2021, Pukul 10.00. 
kewenangan yang berhubungan dengan jabatannya, atau yang menurut pikiran orang yang memberikan hadiah atau janji tersebut ada hubungan dengan jabatannya.

Demikian pula pihak yang memperdagangkan pengaruh dikenai sanksi berdasarkan berlakunya Pasal 55 KUHP, di mana pihak-pihak tersebut dianggap turut serta dalam melakukan suatu tindak pidana. Adapun penjelasan penerapan Pasal 55 KUHP dalam kasus trading in influence adalah sebagai berikut: Pasal 55 KUHP menyatakan bahwa yang dianggap sebagai pembuat (dader) suatu tindak pidana bukan hanya pelaku (pleger) saja. Salah satu peran yang dapat dikenai sanksi pidana adalah pihak yang turutserta (medepleger). Menurut Barda Nawawi Arief undang-undang tidak memberikan definisi tentang medepleger (orang yang turut serta), Memorie van Toelicting menyatakan orang yang turut serta melakukan (medepleger) ialah orang yang dengan sengaja turut berbuat atau turut mengerjakan terjadinya sesuatu. ${ }^{18}$ Dengan demikian pelaku perdagangan pengaruh dapat dikenai sanksi pidana sebagai pihak yang turut serta melakukan kejahatan karena di antara para pihak terdapat unsur kerjasama yang disengaja/disadari, sehingga peristiwa kejahatan tersebut terjadi.

Berdasarkan pasal-pasal yang diuraikan di atas, unsur delik yang penting adalah adanya tindakan memberi / menjanjikan sesuatu kepada pegawai negeri atau penyelenggara negara, dan pada diri pegawai negeri atau penyelenggara negara terdapat unsur menerima hadiah / pemberian. Hal tersebut menggambarkan adanya transaksional dalam aktivitas suap di antara para pihak yang terlibat. Dalam hal unsur suap terpenuhi, maka para pihak dapat dikenai sanksi pidana berdasarkan pasal-pasal tersebut. Sejauh ini, pihak yang terlibat dalam tindakan trading in influence memang dikenakan pasal suap karena mereka menerima sejumlah uang, walaupun hal ini tidak sepenuhnya tepat karena pelaku perdagangan pengaruh tidak melakukan perbuatan yang bertentangan dengan jabatannya.

Hal yang penting untuk dikaji lebih lanjut adalah terdapat kemungkinan bahwa tindakan trading in influence dapat terjadi baik disertai dengan perbuatan suap ataupun tanpa perbuatan suap. ${ }^{19}$ Di sinilah kita melihat masih adanya kekosongan hukum, karena tanpa adanya suap, aktivitas perdagangan pengaruh dapat saja terlepas dari jerat hukum. Pada dasarnya tindakan trading in influence memiliki keterkaitan / korelasi dengan TIPIKOR. Trading in influence dapat dikatakan sebagai perbuatan yang bersifat koruptif. Sama halnya dengan tindakan korupsi, trading in influence mengandung sifat adanya penghianatan kepercayaan. Terdapat kaitan antara perdagangan pengaruh dengan adanya kekuasaan pada salah satu pihak yang terlibat. Penyalahgunaan kekuasaan ini merupakan salah satu unsur dari tindak pidana korupsi jika tindakan tersebut dapat menimbulkan kerugian terhadap keuangan negara.

18 Arief BN, Sari Kuliah Hukum Pidana Lanjut (Badan Penyediaan Bahan Kuliah Fakultas Hukum Universitas Diponegoro 2007, hlm.41.

19 Nefa Claudia Meliala, "Urgensi Kriminalisasi Perdagangan Pengaruh dalam Pembaharuan Hukum Pidana", $\quad$ https://www.hukumonline.com/berita/baca/lt5c45574b1e6e9/urgensi-kriminalisasiperdagangan-pengaruh-dalam-pembaharuan-hukum-pidana-oleh--nefa-claudia-meliala?page=2, diakes Pada Tanggal 17 Januari 2021, Pukul 11.00. 
Trading in influence dapat dilakukan baik oleh pejabat publik atau penyelenggaran negara, maupun bukan pejabat publik.Undang-Undang Nomor 31 Tahun 1999 sebagaimana diubah dengan Undang-Undang Nomor 20 Tahun 2001 Tentang Pemberantasan Tindak Pidana Korupsi belum mengklasifikasikan tindakan trading in influence sebagai delik tersendiri. Dengan demikian diperlukan revisi UU Pemberantasan Tipikor, dengan memasukan unsur tindakan trading in influence.

\section{Urgensi Kriminalisasi Tindakan Perdagangan Pengaruh (Trading in Influence) Dalam Rangka Optimalisasi Pemberantasan TIPIKOR.}

Praktik Trading in Influence yang marak terjadi mengalami perkembangan modus yang kompleks. Keterbatasan aturan pidana yang berlaku mengakibatkan para pelaku sulit untuk dijerat. Kasus korupsi yang di dalamnya terdapat unsur trading in influence mengakibatkan pihak-pihak yang terlibat dikenai sanksi berdasarkan berlakunya pasal suap dan gratifikasi. Dengan demikian perlu dibahas lebih lanjut apakah merupakan hal yang urgen untuk mengatur tindakan trading in influence dalam pasal tersendiri? Dengan kata lain apakah tindakan trading in influence perlu dianggap sebagai delik tersendiri? Ataukah keberadaan pasal-pasal di dalam UU Tipikor dan pasal-pasal terkait dengan penyertaan tindak pidana di dalam KUHP telah cukup untuk menjerat para pelaku? Untuk menjawab hal tersebut, akan dianalisis beberapa contoh kasus yang terjadi.

1. Kasus Penetapan Kuota Impor Daging Sapi, yang melibatkan Lutfi Hasan Ishaaq, yang mencoba mempengaruhi Menteri Pertanian Suswono untuk menambah kuota impor daging sapi. Dalam kasus ini Elda Devianne Adiningrat (orang kepercayaan Maria) mempertemukan Maria Elizabeth Liman (Pemilik PT. Indoguna Utama) dengan Ahmad Fathanah (orang kepercayaan Luthfi Hassan Ishaaq). Maria meminta bantuan terkait penambahan kuota impor daging sapi untuk PT. Indo guna Utama pada semester II tahun 2012 dan menyatakan akan memberikan dukungan kepada PKS serta meminta dikenalkan dengan Luthfi Hassan Ishaaq. Maria meminta Luthfi Hassan Ishaaq agar membantu pengurusan penerbitan rekomendasi dari Kementan atas permohonan penambahan kuota impor daging sapi 8000 Ton yang diajukan oleh PT. Indoguna Utama. Kemudian Luthfi Hasan Ishaaq sanggupi permintaan tersebut dan memerintahkan Maria agar menyiapkan data sebagai bahan diskusi dengan Suswono (Menteri Pertanian).

Berdasarkan surat dakwaan Jaksa Penuntut Umum, Luthfii yang juga Presiden Partai Keadilan Sejahtera (PKS), telah menerima uang sejumlah satu milyar rupiah dari PT. Indoguna utama yang merupakan salah satu importir sapi terbesar di Indonesia. Uang yang diterima Luthfi diberikan yaitu sebagai imbalan agar Luthfi selaku Presiden PKS dapat membantu mempengaruhi Menteri Pertanian (dalam hal ini merupakan bawahannya di Partai PKS) untuk dapat menambah kuota impor daging sapi bagi PT. Indoguna Utama.

Dalam hal ini penulis berpendapat bahwa dalam kasus ini yang terjadi, adanya kesamaan bentuk trilateral relationship pola horizontal dalam kasus Lutfi Hasan Ishaaq. Kedudukan para pelaku apabila merujuk pada kasus korupsi tersebut, maka 
kedudukan Lutfhi Hasan Isaaq sebagai orang yang memperdagangkan pengaruh, PT Indoguna Utama dan Ahmad Fathana selaku orang kepercayaan Lutfhi sebagai klien yang berkepentingan dan broker, dan Menteri Pertanian sebagai Pengambil kebijakan.

Surat dakwaan JPU memuat frasa "mempengaruhi". Frasa "mempengaruhi" masuk dalam ruang lingkup trading in influence yang mempunyai hubungan dengan tindak pidana korupsi. Hubungan sifat Perdagangan Pengaruh dengan tindak pidana korupsi yaitu hubungan saling interdependensi antara sifat dari korupsi yang menjelma pada sifat trading in influence sebagai pemicu munculnya tindak pidana korupsi. Titik utama dari trading in influence adalah nilai pengaruh.

2. Kasus Proyek Hambalang: Tindakan Trading in Influence yang dilakukan pada kasus Anas Urbaningrum, terkait dengan pengaruh yang sangat besar pada diri Anas Urbaningrum untuk mengatur proyek-proyek pemerintah yang dananya berasal dari Anggaran Pendapatan dan Belanja Negara (APBN). Fakta ini berdasarkan Putusan No. 74/PID/TPK/2014/PT.DKI. Pengaruh yang dilakukan Anas Urbaningrum semakin besar setelah Ia mencalonkan diri menjadi Anggota DPR-RI dari partai Demokrat dan terpilih menjadi anggota DPR-RI periode 2009-2014 serta ditunjuk menajadi Ketua Fraksi Partai Demokrat di DPR-RI. Hubungan Anas Urbaningrum selaku anggota DPR-RI dengan Perusahan- Perusahaan seperti PT Adhi Karya, PT Dutasari Citralaras, dan Permai Group merupakan suatu hubungan kolusi.

Dalam hal ini PT Dutasari Citralaras (PT DCL) berperan dalam menampung upah atas megaproyek tersebut kemudian mengalokasikannya ke Menteri Pemuda dan Olahraga Andi Mallarangeng, Anas Urbaningrum, serta ke DPR. Proyek tersebut telah direncanakan sejak awal dalam rangka mendukung Anas untuk menjadi Ketua Umum Partai Demokrat. Bahkan sang istri, Athiyyah Laila, sudah pernah diperiksa KPK. Athiyyah diperiksa terkait posisinya sebagai komisaris dan pemegang saham PT Dutasari Citralaras, perusahaan yang menjadi subkontraktor dalam proyek ini.

Anas Urbaningrum tidak mempunyai kewenangan dalam mengambil kebijakan, yang mana kebijakan ada di kekusaan Andi Alifian Mallarangeng sebagai Menteri Kementerian Pemuda dan Olahraga. Anas Urbaningrum juga bukan pejabat di lingkungan Kementerian Pemuda dan Olahraga tetapi Anas Urbaningrum mempunyai pengaruh, dapat mempengaruhi atau menentukan proyek - proyek dan siapa yang akan memenangkan tender.

Terhadap kasus ini adanya kesamaan dengan bentuk trilateral relationship pola Vertikal dengan Broker. Merujuk pada pola tersebut maka kedudukan Anas Urbaningrum dapat ditempatkan pada posisi orang yang mempunyai pengaruh, PT Adhi Karya, PT DCL. Permai Grup PT Duta Graha Indah berada di Posisi klien yang mempunyai kepentingan. Sedangkan Atiyah Laila, Mindo Rosalina sebagai Calo atau broker dan Andi Alifian Mallarangeng dan Wafid Muharram sebagai Menteri dan sekertaris Kementerian Pemuda dan Olahraga adalah orang yang mempunyai kewenangan atau pengambil kebijakan. 
Berdasarkan uraian dari dua contoh kasus di atas, nampak adanya pengaruh yang signifikan dari tindakan trading in influence terhadap terjadinya tindakan melawan hukum baik berupa delik suap ataupun korupsi. Rencana pihak yang berkepentingan untuk memperkaya diri, sangat terbantu pelaksanaannya oleh adanya pihak yang memperdagangkan pengaruhnya karena ia membuka akses hubungan antara pihak yang berkepentingan dengan pihak penentu kebijakan / pemegang kekuasaan.

Saat ini, modus korupsi yang dilakukan adalah dengan memberikan suap atau gratifikasi, bukan kepada pemilik kewenangan, melainkan kepada orang yang memiliki posisi atau hubungan dekat atau erat dengan orang yang mempunyai kewenangan. Posisi atau hubungan yang dekat atau erat dengan orang-orang yang mempunyai kewenangan tersebut diharapkan oleh pemberi suap dapat mempengaruhi pemilik kewenangan untuk melakukan atau tidak melakukan sesuatu dalam kewenangannya yang menguntungkan pemberi suap. Dalam konteks inilah terjadinya Trading in Influence. ${ }^{20}$ Hal ini menunjukan perlunya regulasi yang bersifat khusus terhadap tindakan tersebut.

Seringnya, terjadi berbagai kasus Trading in Influence, namun pengaturan dalam UU Tentang PTPK hanya memabahas mengenai delik suap yang dilakukan oleh penegak hukum dan pemerintah. ${ }^{21}$ Pada kasus di atas, pihak yang memperdagangkan pengaruh menerima sejumlah uang sehingga dalam hal ini Jaksa Penuntut Umum mendakwa dengan menggunakan pasal suap, padahal antara Trading in Influence dengan suap memiliki makna yang sangat berbeda. Apabila dalam kasus di atas seandainya tidak terjadi penerimaan sejumlah uang oleh yang memperdagangkan pengaruhnya maka, akan terjadi kekosangan hukum dalam hal pertanggungjawaban pidananya karena hukum positif di Indonesia belum mengaturnya.

Sebagai contoh/ilustrasi kasus: A adalah seorang kerabat dari B. A bukan berasal dari kalangan pejabat publik sedangkan B adalah seorang pejabat publik di sebuah kementerian. A melakukan pendekatan kepada $\mathrm{C}$ yang merupakan seorang pebisnis. untuk memasukan penawaran terkait adanya proyek pengadaan barang di instansi yang dipimpin oleh $\mathrm{B}$. A menjanjikan kepada $\mathrm{C}$ bahwa $\mathrm{C}$ akan dimenangkan dalam proses tender, asalkan $\mathrm{C}$ bersedia melakukan mark up harga. $\mathrm{C}$ melakukan hal tersebut tanpa memberi suap kepada B dan tanpa memberikan apapun kepada A. Keuntungan diperoleh secara bersama-sama dari hasil mark up. Dalam hal ini A melakukan perdagangan pengaruh, B melakukan tindakan korupsi. B dan C dapat dikenai sanksi Pasal 2 UU Tipikor, namun pasal yang dapat menjerat A sebagai perantara, belum ada di dalam peraturan perundang-undangan di Indonesia.

Peraturan hukum pidana di Indonesia perlu mengatur tindakan trading in influence sebagai tindak pidana tersendiri. Dalam hal ini berarti diperlukan kriminalisasi atas tindakan tersebut. Dalam tahapan kriminalisasi, tentunya akan ditempuh tahap formulasi yaitu perumusan tindak pidana. Dalam merumuskan tindakan trading in influence dalam

20 Policy Paper, Op.cit. hlm. 28.

21 Dimas Jarot Bayu, "Dagang Pengaruh Marak Dinilai Karena Uu Tipikor Lemah", Https://Nasional.Kompas.Com/Read/2016/09/18144741/Dagang.Pengaruh.Marak, diakses Pada Tanggal 12 Januari 2021, Pukul 07.00. 
hukum pidana di Indonesia, perlu diperhatikan mengenai kualifikasi mereka yang dianggap memiliki pengaruh yang dapat mempengaruhi pejabat publik atau penyelenggara negara atau perorangan untuk melakukan atau tidak melakukan sesuatu berdasarkan wewenang yang dimilikinya serta bagaimana pertanggungjawaban pidana bagi para pelaku trading in influence yang melakukan baik dalam bentuk pasif maupun dalam bentuk aktif.

Perumusan trading in influence sebagai sebuah delik yang mandiri diharapkan dapat menjamin kepastian hukum di Indonesia. Menurut Sudikno Mertukusumo, kepastian hukum merupakan sebuah jaminan bahwa hukum tersebut harus dijalankan dengan cara yang baik. Kepastian hukum menghendaki adanya upaya pengaturan hukum dalam Perundang-undangan yang dibuat oleh pihak yang berwenang dan berwibawa, sehingga aturan-aturan itu memiliki aspek yuridis yang dapat menjamin adanya kepastian bahwa hukum berfungsi sebagai suatu peraturan yang harus ditaati. ${ }^{22}$ Kepastian merupakan ciri yang tidak dapat dipisahkan dari hukum, terutama untuk norma hukum tertulis. Hukum tanpa nilai kepastian akan kehilangan makna karena tidak dapat lagi digunakan sebagai pedoman perilaku bagi setiap orang. Dalam memahami nilai kepastian hukum yang harus diperhatikan adalah bahwa nilai itu mempunyai relasi yang erat dengan instrumen hukum yang positif dan peranan negara dalam mengaktualisasikannya pada hukum positif.

Perumusan delik trading in influence di Indonesia sebagai tindak pidana korupsi dinilai sangat urgen dalam rangka mengoptimalisasi pemberantasan tindak pidana korupsi karena tidak selamanya pelaku adalah penyelenggara negara atau pegawai negeri. Berdasarkan kasus-kasus yang telah diputus melalui proses peradilan, subjek pelaku tindak pidana merupakan pegawai negeri atau penyelenggara negara, sehingga memang dimungkinkan untuk diproses melalui UU PTPK. Dalam hal pelaku bukan pegawai negri atau penyelenggara negara, pasal suap menjadi sulit untuk diterapkan.

\section{KESIMPULAN}

Berdasarkan uraian pembahasan di atas, beberapa kesimpulan yang dapat diambil yaitu:

1. Pengaturan tindakan Trading in influence dalam sistem hukum di Indonesia adalah sebagai berikut: Penegakan hukum didasarkan pada berlakunya Pasal 5, Pasal 11, dan Pasal 12 Huruf a dan b UU No 31 Tahun 1999 tentang Pemberantasan Tindak Pidana Korupsi (UU PTPK) sebagaimana diubah dengan UU No 20 Tahun 2001 dan Pasal 55 KUHP tentang keturutsertaan dalam melakukan tindak pidana. Kelemahan penegakan hukum saat ini adalah bahwa pasal suap dan gratifikasi dalam UU Pemberantasan Tipikor hanya dapat diterapkan bagi penyelenggara negara yang menerima suap atau gratifikasi dalam rangka melakukan suatu perbuatan yang bertentangan dengan tugas dalam jabatannya.

2. Kriminalisasi terhadap tindakan trading in influence sebagai tindak pidana tersendiri menjadi sesuatu yang urgen untuk dilakukan. Dalam perkembangannya, kasus

22 Asikin zainal, Pengantar Tata Hukum Indonesia, Jakarta: Rajawali Press, 2012 
korupsi dilakukan dengan modus yang kompleks, serta melibatkan pihak yang menjadi "perantara" antara pihak yang berkepentingan, dengan pihak yang memiliki kekuasaan. Suap diberikan pada orang yang memiliki kedekatan atau akses terhadap kekuasaan. Suap dapat saja diberikan pada pihak yang tidak memiliki kekuasaan secara langsung (bukan penyelenggara negara). Posisi atau hubungan yang dekat atau erat dengan orang-orang yang mempunyai kewenangan tersebut diharapkan oleh pemberi suap dapat mempengaruhi si pemilik kewenangan untuk melakukan atau tidak melakukan sesuatu dalam kewenangannya yang menguntungkan pemberi suap. Saat ini, pihak yang memperdagangkan pengaruh hanya dapat dituntut atas dasar tindakan turut serta atau membantu terjadinya penyuapan.

Adapun saran yang dapat disampaikan di antaranya:

1. Pembentuk undang-undang perlu merevisi UU Tipikor dengan menambahkan aturan terkait dengan trading in influence.

2. Perumusan pasal trading in influence dalam hukum pidana di Indonesia, perlu memperhatikan kualifikasi pelaku. Siapa yang dianggap "memiliki pengaruh sehingga dapat mempengaruhi pejabat publik atau penyelenggara negara untuk melakukan atau tidak melakukan sesuatu berdasarkan wewenang yang dimilikinya serta bagaimana pertanggungjawaban pidana bagi para pelaku trading in influence yang melakukan tindakan baik dalam bentuk pasif maupun dalam bentuk aktif.

\section{DAFTAR PUSTAKA}

\section{Buku}

Andi Hamzah, Pemberantasan Korupsi melalui Hukum Pidana Nasional dan Internasional Jakarta: Raja Grafindo Persada, 2007.

Artidjo Alkostar Tim Peneliti Indonesia Corruption Watch, Kajian Implementasi Aturan Trading in Influence Dalam Hukum Nasional, Jakarta; ICW, 2014.

Asikin Zainal, Pengantar Tata Hukum Indonesia, Jakarta: Rajawali Press, 2012

Donal Fariz, dkk, Kajian Implementasi Aturan Trading in Influence Dalam Hukum

Nasional, Jakarta: Indonesia Corruption Watch, 2014

Evi Hartanti, Tindak Pidana Korupsi, Jakarta: Sinar Grafika, 2014.

Miriam Budiarjo, Dasar-Dasar Ilmu Poltik. Jakarta: Gramedia Pustaka Utama, 2007.

Sari Mandina, Hukum Pidana Masa Kini: Perspektif Jurimetrie Pada Kebijakan Legislasi Pemberantasan Tindak Pidana Korupsi, Yogyakarta: Total Media, 2014.

\section{Artikel Jurnal}

Alvin Saputra Dan Ahmad Mahyani, Tinjauan Yuridis Trading In Influence Dalam Tindak Pidana Korupsi, Mimbar Keadilan Jurnal Imu Hukum, 2017.

Anis Lailatul Fajriah, et.al., Perdagangan Pengaruh (Trading In Influence) Ditinjau Dari Perspektif United Nations Convention Against Corruption (UNCAC), e-Journal Komunitas Yustisia, Universitas Pendidikan Ganesha Program Studi Ilmu Hukum (Volume 4 Nomor 2 Agustus 2021) 
Edi Yunara, Korupsi dan Pertanggungjawaban Pidana Korporasi, Bandung: PT Citra Aditya Bakti, Vol.3,2005.

Julia Philipp, The Criminalisation of Trading in Influence in International Anti Corruption Laws, Faculty of Law University of the Western Cape, South Africa, 2009.

Policy Paper, Kajian Implementasi Aturan Trading in Influence, Indonesia Corruption Watch, Jakarta, 2014.

Forum Pemantau Pemberantasan Korupsi, United Nations Convention Against Corruption (UNCAC), 2003 terjemahan, Jakarta: Perum Percetakan Negara RI, 2004.

\section{Peraturan Perundang-undangan}

Undang-undang Nomor 20 Tahun 2001 Tentang Perubahan Atas Undang-undang Nomor 31 Tahun 1999 Tentang Pemberantasan Tindak Pidana Korupsi (LNRI Tahun 2001 Nomor 134, Tambahan Lembaran Negara RI Nomor 4150).

Undang-undang Nomor 7 Tahun 2006 TentangPengesahan United Nations Convention Against Corruption, 2003 (Konvensi Perserikatan Bangsa-Bangsa

\section{Putusan Hakim}

Putusan Hakim Pengadilan Tindak Pidana Korupsi Jakarta No. 38/Pid.Sus/TPK/ 2013/PN.JKT.PST

Putusan Hakim Pengadilan Tindak Pidana Korupsi Jakarta No. 74/PID/TPK/2014/PT.DKI.

\section{Pranala Luar}

Anti Corruption Clearing House, Upaya KPK Menangani Korupsi di Sektor Swasta, https://acch.kpk.go.id/id/component/content/article?id=166:upaya-kpkmenangani-korupsi-di-sektor-swasta, diakses pada tanggal 15 Januari 2021, Pukul 11.00 .

Dimas Jarot Bayu, Dagang Pengaruh Marak Dinilai Karena Uu Tipikor Lemah, Https://Nasional.Kompas.Com/Read/2016/09/18144741/Dagang.Pengaruh.Marak, diakses Pada Tanggal 12 Januari 2021, Pukul 07.00.

Hukum online, Pasal untuk Menjerat Pelaku Suap di Sektor Swasta, https://www.hukumonline.com/klinik/detail/ulasan/lt5f086878a3f65/pasal-untukmenjerat-pelaku-suap-di-sektor-swasta/, diakses Pada Tanggal 20 Mei 2021, Pukul 10.00 .

J Kristiadi, Bersatu Melawan Perdagangan Pengaruh, Harian Kompas Edisi 24 November 2015.

Kabar 24, UU Korupsi Sektor Swasta Harus Segera Hadir, Kenyamanan Investasi Lebih Terjamin,Https://Kabar24.Bisnis.Com/Read/20180221/16/741434/Uu- 
Korupsi-Sektor-Swasta-Harus-Segera-Hadir-Kenyamanan-Investasi-LebihTerjamin, diakses Pada Tanggal 15 Januari 2021, Pukul 11.00.

Nefa Claudia Meliala, Urgensi Kriminalisasi Perdagangan Pengaruh dalam Pembaharuan Hukum Pidana, https://www.hukumonline.com/berita/baca/lt5c45574b1e6e9/urgensikriminalisasi-perdagangan-pengaruh-dalam-pembaharuan-hukum-pidana-oleh-nefa-claudia-meliala?page=2, diakes Pada Tanggal 17 Januari 2021, Pukul 11.00. 